\title{
KIT SOLAR SEL/PANEL SURYA SEBAGAI MEDIAPEMBELAJARAN PADA MATERI EFEK FOTOLISTRIK
}

\author{
Yusra Defawati \\ SMAN 1 Kecamatan Guguak Kabupaten LimaPuluh Kota \\ ysrdfwti@gmail.com
}

Submit, 25-04-2019 Accepted, 30-06-2019 Publish,30-06-2019

\begin{abstract}
: the aim is to motivate students in learning the photoelectric effect, the method used in this study is inquiry learning with the result that students can more easily understand the working principle of solar cells / solar panels so that learning is more edible and students understand it more easily. For students learning with this solar panel kit can add knowledge horizons and apply them, and give birth to new innovations. For teachers to be able to create a fun and meaningful learning atmosphere by further increasing creativity and innovation in learning. Schools as a means for teachers and students to interact can support and support, so that the learning process produces output that is valuable and characterized, and creative.
\end{abstract}

Keywords: Solar cell / solar panel kit, learning media, microscopy, NPN transitor

\begin{abstract}
Abstrak: tujuan penelitin ini adalah untuk memotivasi siswa dalam pembelajaran Efek Fotolistrik, metode yang digunakan dalam penelitian ini adalah inquiry learning dengan hasilnya siswa dapat lebih mudah memahami prisnip kerja solar sel/panel surya sehingga pemebelajaran lebih bermakan dan siswa lebih mudah memahaminya. Bagi siswa pembelajaran dengan kit panel surya ini dapat menambah cakrawala pengetahuan dan menerapkannya, serta melahirkan inovasi-inovasi baru. Bagi guru agar dapat membuat suasana belajar yang menyenangkan dan bermakna dengan lebih meningkatkan kreativitas dan inovasi dalam pembelajaran.

Sekolah sebagai sarana untuk guru dan siswa berinteraksi dapat mendukung dan mensupport, agar proses belajar menghasilkan output yang bernilai dan berkarakter, serta kreatif
\end{abstract}

Kata Kunci: Kit solar sel/Panel surya, media pembelajaran, mikroskopi, transitor NPN

\section{PENDAHULUAN}

Ilmu Fisika di tingkat SMA sudah sampai pada ranah yanglebih kompleks yaitu tingkat analitis, sehingga dalam menyelesaikan materi - materi ilmu fisika perlu menganalisa beberapa komponen. Pembagian materi ilmu fisika dikelompokkan menjadi dua bagian yaitu fisika klasik dan fisika modern. Ilmu fisika klasik bersifat makroskopik yaitu konkrit /nyata pada benda-benda yang dapat teramati langsung, sedangkan ilmu fisika moden bersifat mikroskopik yaitu abstrak/tidak nyata dan tidak dapat teramati secara langsung, misalnya elektron, molekul,dan lain-lain. Fisika klasik pada kurikulum 2006 dipelajari pada kelas X dan XI, sedangkan fisika modern dipelajari pada keas XII di tingkat SMA

Selama mengajar fisika di kelas XII penulis mengalami kesulitan dalam menjelaskan materi fisika modern seperti efek fotolistrik. Karena itu penulis berusaha mencari metoda yang dapat membantu menjelaskan efek fotolistrik, agar siswa bisa dengan mudah memahami tentang efek fotolistrik tersebut. Salah satu upaya yang dicoba untuk dilakukan adalah dengan membuat semacam seperangkat alat dan bahan yang memiliki fungsi tertentu dikemas dalam satu paket yang disebut kit sebagai media dalam mengajar sebagaimana yang diungkapkan oleh Sharon mengemukakan pengertian media (2005) : "A medium (plural, media) is a 
means of communication and source of information ". Media merupakan suatu sarana komunikasi dan sumber informasi. Menurut Rohani (1997) "Media adalah segala sesuatu yang dapat diindra yang berfungsi sebagaiperantara/sarana/alat untuk proses komunikasi". Sadiman (1993) menyatakan bahwa "Media adalah perantara atau pengantar pesan dari pengirim ke penerima pesan". AECT (Association for Educational Communications and Technology, 1979) mengartikan "Media sebagai segala bentuk dan saluran untuk proses transmisi informasi".

Best practice ini penulis beri judul "Kit Solar Sel sebagai media pembelajaran pada materi Efek Fotolistrik di kelas XII IPA SMA N 1 Kecamatan Guguak Kabupaten Limapuluh Kota".Semoga dengan adanya Kit ini dapat menjadi pemicu dan motivasi bagi siswa untuk lebih meningkatkan semangatnya dalam belajar fisika yang mereka anggap sulit, selanjutnya dapat melahirkan inovasiinovasi baru danbervariasi baik bagi gurunya maupun siswa.

\section{LANDASAN TEORI}

Dian Sukmara

(2007)

menyebutkan "proses pembelajaran pada hakikatnya merupakan pemberdayaan potensi kodrati manusia secara utuh dan terpadu menuju derajat dan martabat bagi manusia yang sempurna, yang terwujud dalam bentuk kecakapan hidup". Dalam rangka pencapaian tersebut, guru dalam hal ini terus berusaha menciptakan kondisi pembelajaran yang baik, efektif dan optimal. Apalagi dalam pembelajaran seperti fisika, fisika sebagai mata pelajaran saat ini masih dianggap sulit, salah satu sebabnya adalah materi yang bersifat abstrak, oleh karena itu dalam pelaksanaannya siswa harus dihadapkan pada pemanfaatan konsep fisika secara langsung dan biarkan siswa berusaha sendiri untuk menghadapi permasalahan dengan menggunakan pengetahuan yang mereka dapatkan.

Sehingga melalui model kit ini siswa dapat melihat langusng proeses yang abstrak menjadi konkrit.

\section{METODE PENELITIAN}

Metode yang digunakan adalah inquiry learning dimana dengan metode ini siswa dapat menemukan pengalaman langsung yang selama ini hanya melalui teori yang sifatnya khayal saja.

Metode Inquiry Learning. Metode Inquiry Learning merupakan salah satu metode yang didasarkan pada konsep pembelajaran konstruktivisme. Pandangan konstruktivisme menurut Richardson dalam Wardoyo (2013) adalah sebagai berikut. Constructivismas the position that "individual screate the irown understanding, based upon the interaction of what they already know and believe and the phenomena or ideas with which theycomein contact". Konstruktivisme merupakan sebuah keadaan di mana seorang individu membangun pemahaman mereka sendiri berdasarkan pada apa yang mereka ketahui dan percayai. Jadi, dalam pendekatan konstruktivisme siswa membangun sendiri pemikirannya terhadap suatu konsep berdasarkan pengalaman yang mereka sendiri.

\section{HASIL PENELITIAN}

Hasil dari penelitian ini adalah pembelajaran tentang efek fotolistrik lebih mudah diamati siswa langsung dan kasat mata sehingga mereka lebih mudah paham.

Dalam penelitian ini penulis menggunakan metode pemeblajarn 
demonstrasi dalm hal itu sangat menimbilkaan antusias siswa sehinnga dalam mengisi lembar LKSnya lebih mudah. Siswa dapat digiring melengkapi LKS dan menyelesaikan sol-soal latihan dan tes yang diberikan kepadanya.

\section{PEMBAHASAN}

Prinsip kerja panel surya dikenal dengan prinsip photoelectrica, bahwa foton yang merupakan partikel penyusun cahaya dengan energinya sebesar $\mathrm{E}=\mathrm{hf}$ akan diteruskan pada permukaan logam yang bertindak sebagai katoda, seperti gambar berikut:

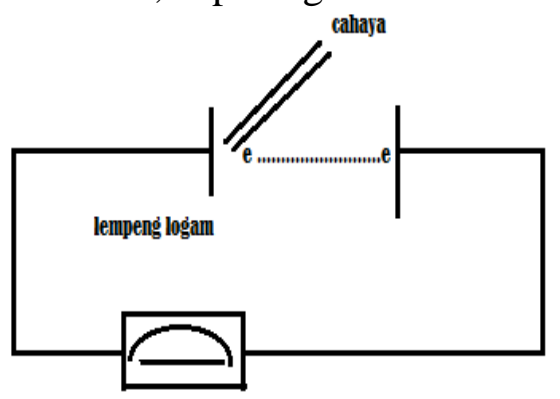

Saat lempeng logam disinari cahaya (f > fo), maka akan terlepas elektron dengan interaksi satu-satu, yaitu setiap satu foton melepaskan satu elektron, energi kinetik maksimum elektron akan menghasilkan tegangan listrik yang diteliti pertama kali oleh Herzt. Hubungan persamaan energi kinetik elektron dengan tegangan listrik yang dihasilkan adalah:

$\mathrm{Ek}_{\text {maks }}=\mathrm{e} . \mathrm{Vo}_{\mathrm{o}}$

Dimana:

$\mathrm{Ek}_{\text {maks }}=$ energi kinetik maksimum (Joule)

$\mathrm{e}=$ muatan elektron $=1,6 \times 10^{-19} \mathrm{C}$

$\mathrm{Vo}=$ tegangan listrik/potensial henti $(\mathrm{V})$

Dan dilanjutkan penelitiannya oleh A.

Einstein yang merumuskan bahwa:

$\mathrm{Ek}_{\text {maks }}=\mathrm{E}-\mathrm{W}_{0}=\mathrm{hf}-\mathrm{hf}_{0}$

Dimana :

$\mathrm{E}=$ energi foton cahaya $(\mathrm{J}$ atau $\mathrm{eV})$

$\mathrm{h}=$ tetapan planck

$\mathrm{f}=$ frekuensi foton/cahaya $(\mathrm{Hz})$
$\mathrm{W}_{0}=$ fungsi kerja/energi ambang

logam $(\mathrm{J}$ atau $\mathrm{eV})$

$\mathrm{f}_{0}=$ frekuensi ambang logam(Herzt)

Peristiwa fotovoltaik ini sulit dalam menjelaskannya kepada siswa secara nyata maka penulis mencari aplikasi yang dapat mendukung tercapainya tujuan pembelajaran ini, sebagaimana diungkapkan oleh A. Tafsir dan U. Usman berikut : “ Aplikasi adalah sebagai kemampuan siswa dalam menggunakan konsepkonsep abstrak, pada objekobjek khusus dan konkrit" (A. Tafsir, 1997), dan "Kata-kata yang dapat dipergunakan dalam aspek aplikasi adalah menghitung, mendemontrasikan, memecahkan masalah, menggunakan" (U. Usman, 1999). Akhirnya tercipatalah kit sel surya ini yang penulis gali informasinya dari media internet. Menurut Gagne dalam Ratna Wilis Dahar (1989) : Pembelajaran fisika menggunakan kit multimedia memungkinkan siswa berinternalisasi dengan lingkungan melalui peralatan atau simbol. Melalui kit multimedia siswa dapat memahami materi atau konsep fisika secara langsung melalui presentasi, demonstrasi dan eksperimen. Informasi-informasi yang telah atau yang akan diterima siswa diproses melalui peralatan yang dirangkai dalam kit multimedia, dengan metoda pembelajaran yang digunakan adalah eksplorasi.

Kit solar sel merupakan suatu sistem produksi listrik dengan memanfaatkan tenaga surya merupakan sistem alami yang cukup populer saat ini. Namun, di sisi lain penggunaan solar panel tergolong masih mahal untuk digunakan pada skala kecil seperti rumah tinggal.

Pembuata Kit Sel Surya ini tersusun dari beberapa transistor jengkol yang cangkangnya dibuka 
terlebih dahulu dengan cara digergaji. Selanjutnya disolder pada papan VCB Rangkai pada papan VCB secara seri masing-masing 5 buah dan di paralelkan dengan kaki Basis merupakan kutub negatif dan kaki Emiter yang dijumper dengan kaki Colector merupakan kutub positif seperti gambar berikut :

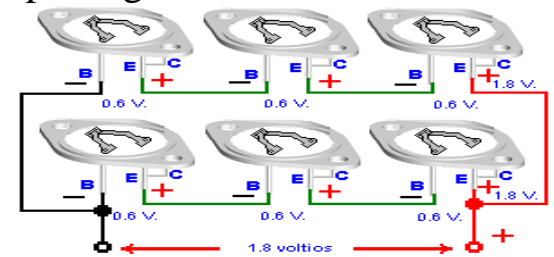

Gambar 1 : Skema rangkaian transistor sebagai panel sel surya

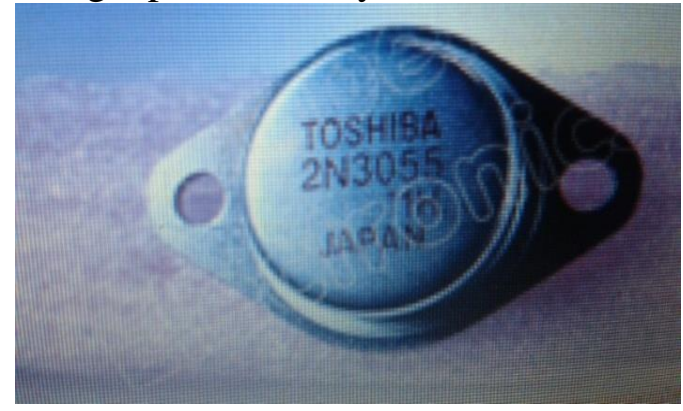

Gambar 2 : Transisitor Jengkol 2N3055 sebagai komponen panel surya

Rangkaian transisitor jengkol ini lalu dihubungkan pada alat yang akan dihidupkan, misalnya pada kalkulator (gambar 3.) dan sebagai tenaga suryanya digunakan lampu sorot (gamabr 4.)

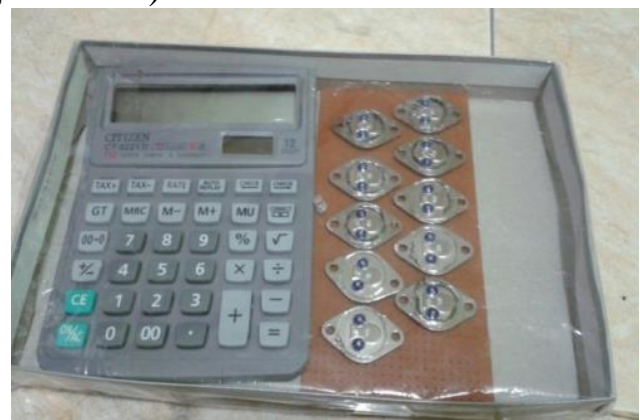

Gambar 3 : Rangkaian susunan Kit Sel Surya

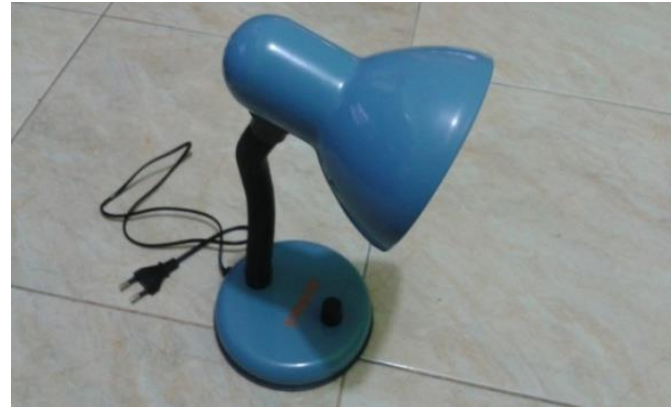

Gambar 4 : Lampu Sorot sebagai sumber cahaya pengganti matahari

Kit panel surya dengan menggunakan transistor jengkol merupakan salah satu dari sekian banyak alternatif pilihan yang dapat membantu menjelaskan materi pembelajaran tentang efek fotolistrik, sekaligus dapat berfungsi sebagai sarana untuk membuka cakrawala pengetahuian siswa bahwa sumber energi listrik alternatif dari tenaga surya, yang sering kita kenal dengan PLTS ( Pembangkit Listrik Tenaga Surya) dapat menjadi salah satu pilihan. ALAT DAN BAHAN

Pembuatan Kit Solar Sel/Panel surya sederhana ini diperlukan alat dan bahan sebagai berikut :

1. Transistor jengkol NPN, seperti type 2N3055 ( 10 buah)

2. Papan VCB (1 buah)

3. Timah( 1 gulungan kecl)

4. Solder(1 buah)

5. Kabel ukuran kecil

6. Kalkulator yang menggunakan baterai dengan bantuan cahaya

7. Multitester

8. Lampu sorot sebagai sumber cahaya Cara Pembuatan :

1. Buka tutup casing transistor jengkol dengan cara menggergaji bagian yang menonjolnya (yang ada tulisan dan no. kodenya) dengan syarat bagian dalamnya tidak boleh rusak saat menggergajinya.

2. Rangkai pada papan VCB secara seri masing-masing 5 buah dan di paralelkan dengan kaki Basis merupakan kutub negatif dan kaki 
Emiter yang dijumper dengan kaki Colector merupakan kutub positif.

3. Solder dengan timah masing-masing kaki transisitor tersebut, cek dengan multitester apakah rangkaian transistor sudah benar dan menghasilkan arus listrik.

4. Hubungkan pada alat/benda yang akan dihidupkan dengan panel surya

5. Hidupkan lampu sorot dan arahkan pada papan VCB yang merupakan panel suryanya.

\section{SIMPULAN}

Dari uraian makalah di atas dapat disumpulkan bahwa kit solar sel/panel surya sebagi media pembelajaran pada matewri efek fotolistrik merupakan salah satu inovasi yang dapat mempermudah dan mendekatkan siswa pada aplikasi yang nyata dari poroses belajar, sehingga siswa tidak menganggap materi fisika sulit dan membingungkan.

Kit sel surya dengan menggunakan transistor jengkol merupakan salah satu model untuk menerapkan prinsip efek fotolistrik sebagai pembangkit tenaga surya.

Adapun saran yang dapat penulis sampaikan adalah :

Bagi siswa pembelajaran dengan kit panel surya ini dapat menambah cakrawala pengetahuan dan menerapkannya, serta melahirkan inovasi-inovasi baru.
Bagi guru agar dapat membuat suasana belajar yang menyenangkan dan bermakna dengan lebih meningkatkan kreativitas dan inovasi dalam pembelajaran.

Sekolah sebagai sarana untuk guru dan siswa berinteraksi dapat mendukung dan mensupport, agar proses belajar menghasilkan output yang bernilai dan berkarakter, serta kreative.

\section{DAFTAR PUSTAKA}

Arif S Sadiman. (1993). Media Pendidikan: Pengertian, Pengembangan, dan Pemanfaatannya. RajaGrafindo Persada. Jakarta.

Dahar, R. W. (1989). Teori Belajar, Jakarta: Erlangga Press

Rohani, A. (1997). Media intruksional Edukatif. Jakarta: PT Rineka Cipta.

Sharon. (2005). Instructional Technology and Media for Learning. Colombos Ohio: New Yersey

Sukmara, D. (2007). Implementasi Skill dalam KTSP. Bandung: Mughni Sejahtera

Wardoyo, S.M. (2013). Pembelajaran Konstruktivisme. Bandung: Alfabeta. 